We run from

the sanctified

moon machine.

\title{
If I'm Bored SAying If I Tell
}

1

What I am really thinking:

Bodies of insects

Sliced-sliced open

So all the jelly shows from their worm body

About to be squeezed out

Onto the table.

I like the pink parts best.

I like the gook inside.

Can I help my hands wanting to do things to their body?

2

No. But I will sit here and wait,

Drinking my tea.

Blooding tea (fine fine)

I will let you know

When I feel my teeth and want to do things

To other things.

I look around in a bad way.

I look for a correct thing.

Sometimes I look at my wrists,

Then my hands start screaming.

My hands stop reading

And just scream.

3

I love to watch

Things on television.

I don't care about a story

Or not, just to watch people do things. 
I like that.

I feel like doing against-things.

But then I just sit there and watch.

Waiting.

4

Someday I bet something huge

Fucking-to-hell life (and all else) will happen with me in it

People will have misrealized what was there

In me (it's in me right now) all that time in me

They'll say little surprise-things - so there -

And I just nod my head.

I drink my tea.

I take care of myself.

I wait for the huge thing that is going to happen.

It will come with silence, leaving marks on my skull.

5

Winter looked at me with horse-eyes

That I believed in.

I believed that warm would come,

Then to feel better.

I got tired of being that way.

The house was full of garbage that I could smell.

I said, "Somebody should do something."

But no one was in the house when I said it, not even me. Hmmmmm.

Then I figure an answer

I think in math and write down lots of numbers

And shapes. I write little hieroglyphic

Fish fish fish fish antelope

With white ears and antlers crawling up out

The head. Jelly in the eyes,

La la la looking into the eyes. Do you trust

Me? Call me 
6

On the telephone. I like

To talk on

The phone. I like

Movies about prostitutes. I like

Girls but I don't like

Being a girl. I like to cut

My hair short. (If the gnome

In the story is wicked, he will

Wear clothes branding him

With CRIME and he will have evil

Gestures, to boot.) But I am flailing

Off my glossary of words to let

You understand things, to tell

What I feel in the fastness

Of never-stop. Do you

Tap into my speed, my slick dictionary of "consternation?"

7

Numbers. We read numbers

They help us along. I shake so nerfous.

Faster time in me than you I bet.

Music, crush me on the inside,

I want to be lifted up.

Send me a message, here.

I want to talk I want to write myself

Safe. But until then, I don't have a thing

8

To say. Nobody does.

9

My bones are lying in middle of me.

Count them. They are taking a bath. 
I know what to do, too.

I know what to do:

I will stare the fizz out of my wrists and drink my tea

And tanks of water.

Fish. Fish. I will survive

This little speak (this little speck) and another and another.

I will go on. It will bring me a friend.

\section{All LIFE}

For instance, if we took a battering ram

To this here door because it's in our way,

We'd end up where we always wanted to be.

Isn't that right? Because good things come

Our way but only in tiny throbbings. Hell,

I wouldn't sell my soul for all the rum

Cokes in the world. Oh, honey, love me on

And do what all $I$ tell you, no one else:

Keep your good eye on the road and if you're driving,

Signal, so the deadbeats know what all you're doing.

Give them a chance. Forever is a long time on

The freeway. You make the access lane, you hope

To merge. It's like joining other blood cells

In a vein, swimming in that stuff, against the pulse.

\section{I'M Talking To You}

You never said lonely would feel this way.

From here, I can see the ferry nose on in

Like the phrases from songs I can't wait

To forget. Sea birds, saying the same thing 